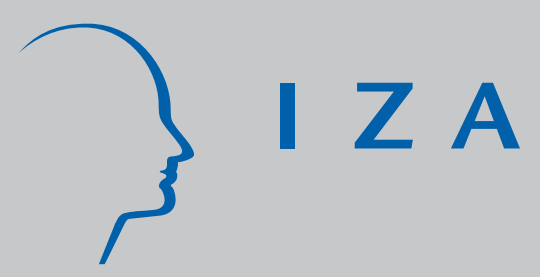

IZA DP No. 429

Does Future PC Use Determine Our Wages Today?

Evidence from German Panel Data

Silke Anger

J ohannes Schwarze

February 2002 


\title{
Does Future PC Use Determine Our Wages Today? Evidence from German Panel Data
}

\author{
Silke Anger \\ Humboldt University, Berlin \\ Johannes Schwarze \\ University of Bamberg, DIW Berlin and IZA, Bonn \\ Discussion Paper No. 429 \\ February 2002 \\ IZA \\ P.O. Box 7240 \\ D-53072 Bonn \\ Germany \\ Tel.: +49-228-3894-0 \\ Fax: +49-228-3894-210 \\ Email: iza@iza.org
}

This Discussion Paper is issued within the framework of IZA's research area The Future of Labor. Any opinions expressed here are those of the author(s) and not those of the institute. Research disseminated by IZA may include views on policy, but the institute itself takes no institutional policy positions.

The Institute for the Study of Labor (IZA) in Bonn is a local and virtual international research center and a place of communication between science, politics and business. IZA is an independent, nonprofit limited liability company (Gesellschaft mit beschränkter Haftung) supported by the Deutsche Post AG. The center is associated with the University of Bonn and offers a stimulating research environment through its research networks, research support, and visitors and doctoral programs. IZA engages in (i) original and internationally competitive research in all fields of labor economics, (ii) development of policy concepts, and (iii) dissemination of research results and concepts to the interested public. The current research program deals with (1) mobility and flexibility of labor, (2) internationalization of labor markets, (3) the welfare state and labor markets, (4) labor markets in transition countries, (5) the future of labor, (6) evaluation of labor market policies and projects and (7) general labor economics.

IZA Discussion Papers often represent preliminary work and are circulated to encourage discussion. Citation of such a paper should account for its provisional character. A revised version may be available on the IZA website (www.iza.org) or directly from the author. 
IZA Discussion Paper No. 429

February 2002

\section{ABSTRACT \\ Does Future PC Use Determine Our Wages Today? Evidence from German Panel Data*}

Using 1985-1999 data from the German Socio-Economic Panel Study (GSOEP) to analyze wages confirms the hypothesis that existing computer wage premiums are determined by individual ability or other unobserved individual characteristics rather than by productivity effects. While a rather large personal computer (PC) wage premium was found in the crosssectional regressions even after the inclusion of standard controls, the conventional longitudinal regression analysis revealed substantially lower or statistically insignificant coefficients, as have other studies. In addition, a new method of testing the two competing explanations for computer wage differentials against each other was found: future PC variables were employed in the wage regressions in order to obtain a further control for worker heterogeneity. The finding that future PC variables have a statistically significant effect on current wages leads one to conclude that computer wage differentials can be attributed to worker heterogeneity rather than to computer-induced productivity.

JEL Classification: J31, O33, C23

Keywords: Computer wage premium, future computer usage, unobserved ability, technological change

Johannes Schwarze

University of Bamberg

Feldkirchenstr. 21

96047 Bamberg

Germany

Tel.: +499518632600

Fax: +499518635569

Email: johannes.schwarze@sowi.uni-bamberg.de

\footnotetext{
* Acknowledgments: We would like to thank seminar participants at Humboldt-University, Berlin.
} 


\section{Introduction}

It is common knowledge that computer skills are remunerated well in the job market. Internships are only available for students with an excellent knowledge of word-processing and spreadsheet analysis, employers require at least one programming language, lectures are inconceivable without a video projector running a sophisticated presentation, statistics are impossible without powerful specialized programs, and informatics students can earn twice the salary of a well-paid economist. The objective of this study is to analyze why knowledge of computer applications pays so well. Of course, computer wage differentials may be justified, because computers enable workers to become more productive, which in turn makes them more valuable to their companies. On the other hand, there is much criticism of computer-related productivity improvements, and reasonable doubt that the PC wage premium is due solely to the increased productivity of computer systems. The question is, to what extent can existing PC wage differentials be attributed to computer-increased productivity, and to what extent can they be explained by individual differences in human capital investment or by unobservable individual characteristics such as ability?

Existing studies of computer wage premiums are divided about whether workers receive a computer wage premium because they are more able or receive one because the new technology increases their productivity. According to the productivity-enhancing hypothesis, workers should be remunerated more highly as soon as they start using a computer at work, while the competing hypothesis states that PC users would already have been better-paid before the introduction of the new technology. Most existing studies of the role of computer technology in changes in the wage structure show that workers who use a computer at work earn 10 - 20\% more than those who do not (see e.g., Krueger 1993, Bell 1996, Miller and Mulvey 1997, and DiNardo and Pischke 1997). One of the first studies to investigate the impact of computer use on wage differentials, by Krueger (1993), finds a computer wage premium of up to $15 \%$ using cross-section data. By contrast, Oosterbeek (1997) shows that, for the Netherlands, the computer wage premium does not vary with the intensity of computer use. He suggests that returns from computer use can be attributed to factors other than the higher productivity of PC-using workers. This might be the case because workers of high ability do the more demanding computer jobs. Gollac and Kramarz (1997) attribute this phenomenon to the frequent occurrence of changes in (computer) technology as well as in organization, where the capacity to adapt to those changes is rewarded. Furthermore, firms anticipate progress in computerization in the near future, and therefore search for a workforce 
that is already adapted to the new technology. DiNardo and Pischke (1997) also doubt any causal relationship between the use of computers at work and wage premiums. Using detailed information on German workers' jobs and on the tools used in those jobs, they find evidence of wage differentials ranging from $9 \%$ to $14 \%$ associated with other "white-collar" tools such as calculators, telephones, and pencils, as well as evidence of a wage penalty linked to "bluecollar" tools. These findings suggest that the tools approximate the occupational wage structure, and that workers who use computers on the job possess unobserved skills, which lead to higher wages.

Whereas cross-section studies are inadequate for capturing the individual components of wage determination, various panel studies have investigated the effect of unobserved heterogeneity on the computer wage premium. Bell (1996) analyzes the impact of computer use on earnings, using data for the United Kingdom. He finds empirical support for the productivity-enhancing explanation in the form of a wage premium for computer use of $17 \%$ after the inclusion of worker and employer characteristics, such as firm size, industry and occupation dummies, and one of $14 \%$ after adding ability test scores. His findings of a positive relation between wages and PC use at work, using cross-section data for 1991, are confirmed by the panel study and by a cross-section study for 1981, in which he uses future skills (observed in 1991) as covariates. Bell (1996) therefore refutes the suggestion that the computer wage premium simply captures unobserved heterogeneity. This interpretation is also supported by Miller and Mulvey (1997) who conduct a cross-section study for Australia.

However, the studies that use matched employee-employer data, by Doms, Dunne, and Troske (1997) for the U.S., and by Entorf and Kramarz (1994, 1997) for France, demonstrate that new technology workers received a wage premium before the introduction of this technology. These studies find that controlling for firm heterogeneity attenuates the wage premium received by workers for using computer-related new technology. In the longitudinal studies by Entorf and Kramarz (1994, 1997), the significance of the computer variables almost completely disappears, whereas the coefficients of computer experience remain significant. They show that the wage premium is due to computer-based new technologies being used by more able workers, which suggests that "firms select their best employees when they need someone to work using computer-based new technology with high autonomy" (Entorf and Kramarz 1994, 24). The preceding results are confirmed by Entorf, Gollac, and Kramarz (1999), who find that the introduction of individual fixed effects into the 
longitudinal model leads to a substantially lower computer wage premium than that obtained in the cross-section study. Therefore, they demonstrate that PC users were already better paid before the new technology was introduced in their jobs, and suggest that "unobserved but compensated characteristics of the workers matter" (Entorf, Gollac, and Kramarz 1999, 464). Haisken-DeNew and Schmidt (1999) doubt that there are computer-use wage differentials worth speaking of in Germany. They find that the significance of coefficients for PC use almost completely disappears in the longitudinal study, and conclude that "for Germany, unobserved individual heterogeneity or ability plays the key role in effectively explaining away the apparent wage premium for using a computer at work" (Haisken-DeNew and Schmidt 1999, 10).

\section{Data}

The data used in this study were made available by the German Socio-Economic Panel Study (GSOEP) at the German Institute for Economic Research (DIW) in Berlin. The GSOEP is a representative longitudinal micro-database that provides a wide range of socio-economic information on private households in Germany. Data were first collected from about 12,200 randomly selected adult respondents (in 6,000 families) in the former West Germany in 1984. After German reunification in 1989, the GSOEP was extended by about 4,500 persons (in 2,200 families) from the former East Germany. In the most recent wave, for 1999, about 13,000 respondents were still participating in the panel study. The GSOEP data is available as a public-use file containing $95 \%$ of the GSOEP sample, with some variables omitted for reasons of data protection (see Wagner et al. 1993, or for more detailed information, HaiskenDeNew and Frick 2000).

We use GSOEP data from 1985 to 1999 for male and female West German full-time employees aged between 20 and 65, excluding foreigners and civil servants. The first wave was excluded, since some questions that are important for this study were not included in 1984. We used an unbalanced panel, and included only those respondents who participated in at least two waves of the survey so that we could control for individual unobserved heterogeneity. In addition, we had to exclude all respondents who had not participated in the survey in 1997, because this is the year in which the information required to construct a variable that indicates PC use was obtained from respondents. In total, the sub-sample consists of 22,361 respondents, while 1,527 observations for 1999 are available for the crosssection study. 
The GSOEP provides detailed information on earnings. Our dependent variable is monthly gross earnings including extra payments, such as the Christmas bonus, holiday pay, income from profit sharing, and other bonuses. Extra payments have become increasingly important in recent years, and Pierce (1999) found that excluding extra payments from earnings tends to understate wage differentials. Since monthly labor income overstates the remuneration of workers whose weekly hours of work exceed 40, it would be appropriate to use the hourly wage rate by dividing earnings by working hours. However, hourly wages as used by Haisken-DeNew and Schmidt (1999) might understate the earnings of managers and other workers who work long hours. Therefore, this study uses total monthly compensation as used by Entorf and Kramarz (1994), and uses working time as a control variable to prevent differences in working hours from distorting the estimates.

All earnings regressions are run separately for men and women and include control variables such as education, experience, age, marital status, five firm size bands, and dummies for six occupations, nine regions, 14 time periods, and 14 industries. The GSOEP also provides information on PC use, which is the central variable in this study, on which a question was only included in the 1997 survey. For that year, the survey indicates whether a respondent used a PC, and identifies the year in which he or she first used a PC at work. The same information was collected on the use of a PC at home. ${ }^{1}$ It is relatively easy to trace back PC use retrospectively for the years before 1997, from the information on when a respondent first used a computer (see Haisken-DeNew and Schmidt 1999, 4). In 1998, only information on the frequency of private PC use was collected, whereas in 1999, respondents were asked only about professional PC use. To obtain a dummy variable for PC use both at work and at home for each wave, we overcame the problem of missing information as follows. If a person used a PC at work or at home in 1997, the dummy variable is set equal to unity in the two subsequent years. If the respondent did not use a PC at work in 1997, the PC dummy is set equal to zero in 1998, and is set equal to unity in 1999 provided the respondent was using a PC at work according to the 1999 survey. If the respondent did not use a PC at home in 1997, but there is evidence of private PC use of at least once a month in 1998, then the PC dummy is set equal

\footnotetext{
${ }^{1}$ The information on computer-use was obtained from the 1997 GSOEP personal questionnaire from the following question: "Do you use a computer at home/at work, and if so, since what year at home/at work?" The original German text reads as follows: "Benutzen Sie privat oder beruflich (bzw. in Ihrer Ausbildung) einen Computer? Gemeint sind hier Personal-Computer (PC) aber auch Grossrechneranlagen, jedoch nicht reine Spielcomputer! [Ja/Nein], ich benutze [einen/keinen] Computer [privat/beruflich] und zwar seit ...”.
} 
to unity in the two subsequent years. If there is no evidence of private PC use in 1997 or 1998, then the PC dummy is set to zero in 1998 and 1999. The 'PC home' variable provides a complete picture of a person's computer utilization, and its inclusion reduces bias in the coefficient of PC use at work "due to omitted factors which are associated with computer-use more generally"(Krueger 1993, 43).

\section{Estimation Methods}

The first model (I) in this study adopts a simple approach to replicate the cross-sectional findings of most studies on PC wage differentials. For 1999, the standard cross-sectional earnings equation is augmented by a dummy variable indicating whether a worker uses a computer at work. In addition, as well as the use of other control variables, a variable for PC use at home is used to capture some of the unobserved individual characteristics. Let $w_{i}$ be individual $i$ 's monthly wage. ${ }^{2}$ The Mincer-type specification of the earnings regression is:

$$
\ln w_{i}=X_{i}^{\prime} b+P C_{i}^{\prime} c+u_{i}
$$

model (I)

where $\mathrm{X}_{\mathrm{i}}$ are standard control variables and $\mathrm{PC}_{\mathrm{i}}$ is a vector of dummy variables, which are equal to unity if the individual uses a computer at work, at home, or both, ${ }^{3} b$ and $c$ are vectors of parameters to be estimated, and $u_{i}$ denotes the unobservable effects. At this point, unobserved individual characteristics will be only partially captured, at best, by adding the PChome variable to the regression for computer wage differentials. Model (II) is very similar to model (I) except that, as in the study by Haisken-DeNew and Schmidt (1999), panel data is used to run a pooled regression as well as random effects and fixed effects estimations in order to control for unobservable individual characteristics:

$$
\ln w_{i t}=X_{i t}^{\prime} b+P C_{i t}^{\prime} c+u_{i t}
$$

An alternative approach to testing the productivity-enhancing hypothesis is to include information on future PC use in a longitudinal analysis, which might capture unobserved worker characteristics. This approach is similar to that of Bell (1996) who, in a cross-section study, regressed the log of hourly wages, not only on standard control variables but also on variables for skills that were measured in a subsequent survey conducted ten years later. The use of the future PC variable is possible given the relatively long panel data period, which can be split into two sub-periods: one from 1985 to 1987, the other post-1987. The former is used

\footnotetext{
${ }^{2}$ In what follows, the wage refers to the total monthly compensation of a worker.

${ }^{3}$ In what follows, these variables are referred to as PCwork, PChome and PCboth.
} 
as another sub-sample on which the longitudinal wage regressions are run. The latter is only used to provide information on whether a PC has been used at work after $1987 .{ }^{4}$ In what follows, this information is referred to as future PC use, as observed from the perspective of the first sub-period. The model can be represented as follows:

$$
\ln w_{i, 85-87}=X_{i, 85-87}^{\prime} b+P C_{i, 85-87}^{\prime} c+P C_{i, 88-99}^{\prime} e+u_{i, 85-87} \quad \text { model (III) }
$$

where dummy variables for computer-use at work after 1987, $P C_{i, 88-99}$, are included. The variables for PC use indicate whether a survey respondent uses a computer at work today (1985-1987) and/or in the future (after 1987). With regard to future PC use, we distinguish between: no PC use at work in either the first or second period; no PC use at work in the first period, but some in the second period; and PC use at work in both the first and second periods. In addition to these dummy variables, more detailed information on future PC use is added to the model; that is, information on when the future PC use at work transpires. A distinction is made between different future PC variables, since PC use in the near future might have a different effect on wages than PC use in the distant future. In the early years of the second period, working with computers at work was evidently rather exceptional given that until 1989 less than 20\% of workers were PC users. However, from 1995 onwards, the proportion of PC users was above 50\%, and rose even more until 1999, when more than twothirds of those surveyed used a computer at work, and PC use at work was rather common. Therefore, four dummy variables are used to distinguish between future PC use occurring before 1987, between 1988 and 1990, between 1991 and 1994, and after 1994. Consequently, the following variables relating to PC use at work are incorporated into the panel study: no PC use today or in the future; no PC use today but some in the immediate future (before 1987); no PC use today but some in the near future (between 1988 and 1990); no PC use today but some in the medium future (between 1991 and 1994); no PC use today but some in the distant future (after 1994); and PC use today and in the future.

Since the future PC-use variables cannot have a causal effect on current wage determination, one might suppose that the coefficients of the future PC variables will not be significant in the regression analysis. However, wages might be statistically affected by these variables. If PC use at work in the future has a statistical influence on wages today, this suggests that the future PC-use variables capture unobserved worker characteristics such as ability, which does

\footnotetext{
${ }^{4}$ This dividing line was drawn in order to obtain future information relating to the longest possible time period (1988-1999) whilst still being able to control for unobserved worker heterogeneity with panel data (1985-1987).
} 
affect earnings. If so, the same might be true of current PC variables. If variables on future PC use are closely related to worker ability, then so too probably are variables on current PC use, which thus capture worker ability rather than productivity effects. This would imply that computer wage differentials merely indicate a wage premium due to unobserved worker characteristics rather than to productivity improvements attributable to computers.

\section{Results}

Compared to the cross-sectional study, in which the wage premium from using a PC at work is around $7 \%$ for men when control variables are included, the computer wage premium estimated by the pooled regression is much smaller, as can be seen in Table 1. When looking at the random effects estimator, it is striking that all coefficients for, and explanatory power of, the PC-use variables are considerably reduced. In the regressions for men, the dummy variable for PC use at work shrinks to around $1 \%$ and loses some of its significance in all three versions of model (II). When the wage equation for female workers is estimated with random effects, all coefficients for the PC use at work variables remain statistically significant, but are substantially reduced to around $2 \%$. Using the Hausman test to test the fixed effects model against the random effects model indicates evidence of a correlation between the individual effects and the regressors. The fixed effects estimator applied to model (II) reveals even more sobering results concerning the wage premium from using a computer at work. The PCwork variable is not statistically significant in the regressions for either men or women. Furthermore, the fixed effects model has significantly negative wage premiums for the PChome variable for men, and a significantly positive coefficient for PCboth.

It is well to pause at this point and reflect on the preliminary findings. Controlling for unobserved heterogeneity the wage premiums for computer usage were substantially reduced in the random effects model. In the fixed effects model, all the variables indicating PC use at work were statistically insignificant. These results indicate that it is not computer-induced productivity, but unobserved yet compensated worker characteristics, that matter. 
Table 1: Model (I) and (II): Regressions with Standard Control Variables

\begin{tabular}{|c|c|c|c|c|c|c|c|c|}
\hline \multirow[b]{3}{*}{ Variable } & \multicolumn{2}{|c|}{ Cross-Section 1999} & \multicolumn{6}{|c|}{ Longitudinal Regressions 1985 - 1999} \\
\hline & \multirow[b]{2}{*}{ Men } & \multirow[b]{2}{*}{ Women } & \multicolumn{2}{|c|}{ Pooled OLS } & \multicolumn{2}{|c|}{ Random Effects } & \multicolumn{2}{|c|}{ Fixed Effects } \\
\hline & & & Men & Women & Men & Women & Men & Women \\
\hline \multirow[t]{2}{*}{ Pcwork } & $0.0641^{* *}$ & $0.0533^{* *}$ & $0.0253^{* *}$ & $0.0629^{* *}$ & $0.0118^{*}$ & $0.0268^{* *}$ & -0.0008 & 0.0130 \\
\hline & (0.0194) & $(0.0311)$ & $(0.0048)$ & $(0.0065)$ & $(0.0048)$ & $(0.0067)$ & $(0.0050)$ & $(0.0072)$ \\
\hline$\chi^{2}$-LM-Test & \multicolumn{8}{|c|}{ Men: 17195.2; Women: 5995.6} \\
\hline Hausman-Test & & & & & \multicolumn{2}{|c|}{ Men: 2973.3} & Women: 3 & 0.1 \\
\hline Pcwork & $0.0564^{* *}$ & 0.0488 & $0.0141^{* *}$ & $0.0576^{* *}$ & $0.0112^{*}$ & $0.0237^{* *}$ & 0.0007 & 0.0110 \\
\hline & $(0.0197)$ & $(0.0313)$ & $(0.0050)$ & $(0.0065)$ & $(0.0050)$ & $(0.0067)$ & $(0.0052)$ & $(0.0072)$ \\
\hline Pchome & 0.0335 & 0.0289 & $0.0403^{* *}$ & $0.0439^{* *}$ & 0.0026 & $0.0304^{* *}$ & $-0.0137^{* *}$ & $0.0209^{*}$ \\
\hline & $(0.0157)$ & $(0.0237)$ & $(0.0050)$ & $(0.0081)$ & $(0.0049)$ & $(0.0079)$ & $(0.0051)$ & $(0.0083)$ \\
\hline
\end{tabular}

$\chi^{2}$-LM-Test

Men: 16816.3; Women: 5936.4

Hausman-Test

Men: 1839.5 ; Women: 8803.8

\begin{tabular}{lcccccccc} 
Pcwork & $0.0566^{*}$ & $0.0726^{*}$ & $0.0122^{*}$ & $0.0564^{* *}$ & 0.0046 & $0.0204^{* *}$ & -0.0078 & 0.0070 \\
& $(0.0233)$ & $(0.0336)$ & $(0.0056)$ & $(0.0068)$ & $(0.0055)$ & $(0.0069)$ & $(0.0057)$ & $(0.0074)$ \\
Pchome & 0.0338 & $0.1254^{*}$ & $0.0340^{* *}$ & $0.0345^{*}$ & -0.0121 & 0.0059 & $-0.0234^{* *}$ & -0.0106 \\
\multirow{2}{*}{ Pcboth } & $(0.0256)$ & $(0.0558)$ & $(0.0079)$ & $(0.0166)$ & $(0.0072)$ & $(0.0148)$ & $(0.0074)$ & $(0.0156)$ \\
& -0.0005 & -0.1156 & 0.0102 & 0.0119 & $0.0242^{* *}$ & $0.0309^{*}$ & $0.0274^{* *}$ & $0.0393^{*}$ \\
& $(0.0318)$ & $(0.0606)$ & $(0.0098)$ & $(0.0186)$ & $(0.0086)$ & $(0.0159)$ & $(0.0088)$ & $(0.0165)$
\end{tabular}

$\chi^{2}$-LM-Test

Men: 16814.3; Women: 5338.1

Hausman-Test

Men: 1233.2; Women: 9632.6

Observations $1070 \quad 457 \quad$ Men: 15536; Women: 6825

Source: GSOEP, 1985-1999.

Notes: ${ }^{*}$ Statistically significant at the $5 \%$ level, ${ }^{* *}$ at the $1 \%$ level. Standard errors in parentheses.

This can be tested further by model (III), where variables for future PC use at work are included in the longitudinal regressions for the years from 1985 to 1987. Information from surveys after 1987 enables analysis of how computer wage premiums may be affected by those future variables which, though unable to have a causal effect on wage determination, 
may be statistically significant, perhaps because they capture unobserved yet compensated worker characteristics. Model III cannot be estimated by the fixed effects estimator because the future PC variables do not vary over time. The regression analysis reveals that not all wage differentials implied by the future PC-use dummies are statistically significant when standard control variables are included (see Table 2). The initial estimates show that both men and women receive a wage premium if they do not use a PC today, but will do so in the future (PC01).

Table 2: Model (III): Longitudinal Regressions with PC Future Variables and Standard Controls

\begin{tabular}{|c|c|c|c|c|}
\hline \multirow{3}{*}{ Variable } & \multicolumn{2}{|c|}{ Estimates for men } & \multicolumn{2}{|c|}{ Estimates for women } \\
\hline & Pooled OLS & Random & Pooled OLS & Random \\
\hline & & Effects & & Effects \\
\hline PC01: Did not use a computer today (1985- & $0.0307^{* * *}$ & $0.0461^{* *}$ & $0.0414^{*}$ & 0.0424 \\
\hline 1987), but in the future (after 1987) & $(0.0116)$ & $(0.0169)$ & $(0.0165)$ & $(0.0227)$ \\
\hline \multirow[t]{2}{*}{ PC11: Used a computer today and in future } & $0.0499^{* *}$ & $0.0762^{* *}$ & $0.0816^{* *}$ & $0.1025^{* *}$ \\
\hline & $(0.0157)$ & $(0.0215)$ & $(0.0220)$ & $(0.0277)$ \\
\hline$\chi^{2}$-LM-Test & \multicolumn{2}{|c|}{691.0} & \multicolumn{2}{|c|}{323.5} \\
\hline PC0: Did not use a computer today, but in & -0.0194 & 0.0282 & 0.0324 & 0.0357 \\
\hline the immediate future (before 1987) & $(0.0372)$ & $(0.0348)$ & $(0.0495)$ & $(0.0412)$ \\
\hline \multirow{2}{*}{$\begin{array}{l}\text { PC1: Did not use a computer today, but in } \\
\text { the near future (between } 1988 \text { and 1990) }\end{array}$} & $0.0423^{*}$ & $0.0541^{*}$ & $0.1020^{* *}$ & $0.1060^{* *}$ \\
\hline & $(0.0174)$ & $(0.0254)$ & $(0.0257)$ & $(0.0372)$ \\
\hline \multirow{2}{*}{$\begin{array}{l}\text { PC2: Did not use a computer today, but in } \\
\text { the medium future (between } 1991 \text { and 1994) }\end{array}$} & $0.0319^{*}$ & $0.0550^{*}$ & $0.0452^{*}$ & 0.0380 \\
\hline & $(0.0161)$ & $(0.0241)$ & $(0.0231)$ & $(0.0340)$ \\
\hline \multirow{2}{*}{$\begin{array}{l}\text { PC3: Did not use a computer today, but in } \\
\text { the distant future (after 1994) }\end{array}$} & 0.0273 & 0.0350 & -0.0311 & -0.0125 \\
\hline & $(0.0180)$ & $(0.0279)$ & $(0.0272)$ & $(0.0379)$ \\
\hline \multirow[t]{2}{*}{ PC11: Used a computer today and in future } & $0.0506^{* *}$ & $0.0728^{* *}$ & $0.0821^{* *}$ & $0.0996^{* *}$ \\
\hline & $(0.0158)$ & $(0.0227)$ & $(0.0219)$ & $(0.0308)$ \\
\hline$\chi^{2}$-LM-Test & \multicolumn{2}{|c|}{689.7} & \multicolumn{2}{|c|}{317.0} \\
\hline Observations & \multicolumn{2}{|c|}{15,536} & \multicolumn{2}{|c|}{6,825} \\
\hline
\end{tabular}

Source: GSOEP, 1985-1999.

Notes: ${ }^{*}$ Statistically significant at the $5 \%$ level, ${ }^{* *}$ at the $1 \%$ level. Standard errors in parentheses. 
The future wage premium for men is around 3\% in the pooled OLS regression and 5\% in the random effects model, whereas women receive a future PC-use premium of around $4 \%$ according to both regressions. An even higher premium is obtained from using a PC today and in the future (PC11). As expected, the coefficients and explanatory power of this dummy variable remain virtually unchanged in both the pooled OLS and random effects specifications when more detailed information on future PC use is added to the model by including variables that indicate when a computer would be used for the first time in the future. The division of the future PC-use variable PC01 into four different dummies, PC0, PC1, PC2, and PC3, which indicate how far into the future is the first use of a PC at work, reveals that the variable does indeed matter. Of the individuals who had not used a PC at work when they were originally surveyed, those who would be using a computer in the near future (PC1) had the highest wage on average. The wage equations for male workers reveal coefficients of up to $6 \%$ for future PC use PC1 and PC2, while PC use in the immediate future (PC0) or distant future (PC3) has no explanatory power. Women who would be using a PC in the near future receive a premium of $11 \%$ relative to those who would not be using a $\mathrm{PC}$ at all. In comparison with the wage premiums from the pooled OLS regression, those from the random effects model were slightly higher.

The estimates show that future computer use seems to have an important statistical effect on wage determination, and one that is almost as strong as that of current computer use. This is evidence against the productivity-enhancing explanation of PC wage differentials, since the statistical influence of future PC use at work on wages today is an indication that future PCuse variables capture worker heterogeneity. Therefore, wages are determined not by future PC use at work (which is impossible anyway), but by unobserved worker characteristics, with future PC use perhaps serving as a proxy for ability. ${ }^{5}$ Due to the close association between future PC-use variables and individual characteristics, which are well-remunerated in the labor market, it is quite probable that current PC use at work, instead of generating productivity effects, captures these same characteristics. This is not to deny that workers who use a computer on the job may indeed be more productive. However, according to the findings of this study, higher productivity is not attributable to the use of computers, but

\footnotetext{
${ }^{5}$ If a person's future PC use does capture his or her ability, one could get real returns to education by including this variable in the Mincer equation, in which case, the effect of ability and other unobservable individual characteristics on the schooling coefficient would be diminished. The inclusion of future PC use in the wage equation would reduce bias by controlling for the self-selection effect, which enables one to measure the purged education effect.
} 
rather to individual worker characteristics. Therefore, computer wage differentials are not due to productivity-enhancing computer technology, but arise rather because more able individuals are more likely to use a computer at work, and these individuals would earn a wage premium even in the absence of computer technology.

\section{Conclusion}

Having used data from the German Socio-Economic Panel Study (GSOEP) to analyze wages, we confirm that international evidence for wage differentials also applies to Germany. As other studies have found, computer wage differentials were substantial in the cross-section study for 1999, after including many worker and firm characteristics. However, cross-section results can be spurious, and greatly influenced by worker heterogeneity, and since the GSOEP does not provide information on measured ability, several types of panel study have been carried out to reduce the influence of unobserved worker characteristics and to increase the reliability of the results. The first approach was the conventional method of making use of panel data for the years from 1985 to 1999 provided by the GSOEP. It was found that computer wage premiums were reduced in the pooled OLS and in the random effects specifications, but did not vanish completely. However, in the fixed effects model, all the variables indicating PC use at work were statistically insignificant. Another approach involved the inclusion of dummy variables indicating future PC use in the longitudinal regression. Since future PC-use variables had a statistical influence on the determination of wages, it can be concluded that current PC-use variables also capture those unobserved worker characteristics that affect earnings. The indications from the applied models are that it is not computer-induced productivity, but unobserved yet compensated worker characteristics, that matter.

\section{References}

Bell, B.D. (1996). Skill-Based Technical Change and Wages: Evidence for a Longitudinal Data Set, The Labour Market Consequences of Technical And Structural Change. Discussion Paper No. 8, University of Oxford.

DiNardo, J.E., J.-S. Pischke (1997). The Returns to Computer-use Revisited: Have Pencils Changed the Wage Structure Too?, Quarterly Journal of Economics, 1, 291-303.

Doms, M., T. Dunne, K.R. Troske (1997). Workers, Wages and Technology, Quarterly Journal of Economics, 112, 253-290. 
Entorf, H., F. Kramarz (1994). The Impact of New Technologies on Wages: Lessons from Matching Panels on Employees and on Their Firms, INSEE Working Paper No. 9407, Institut National de la Statistique et des Etudes Economiques, Série des Documents de Travail du Centre de Recherche en Economique et Statistique, Paris.

Entorf, H., F. Kramarz (1997). Does Unmeasured Ability Explain the Higher Wages of New Technology Workers?, European Economic Review, 41, 1489-1509.

Entorf, H., M. Gollac, F. Kramarz (1999). New Technologies, Wages, and Worker Selection, Journal of Labor Economics, 17 (3), 464-491.

Gollac, M., F. Kramarz (1997). L'ordinateur: un outil de sélection?, Révue économique, 48 (5), 1115-1143.

Haisken-DeNew, J.P., J.R. Frick (1998): Desktop Companion to the German Socio-Economic Panel Study (GSOEP), German Institute for Economic Research, Berlin.

Haisken-DeNew, J.P., C.M. Schmidt (1999). Money for Nothing and Your Chips for Free? The Anatomy of the PC Wage Differential, DIW Discussion Paper No. 178, German Institute for Economic Research, Berlin.

Krueger, A.B. (1993). How Computers have Changed the Wage Structure: Evidence from Microdata, 1984-1989, Quarterly Journal of Economics, 1, 33-60.

Miller, P., C. Mulvey (1997). Computer Skills and Wages, Australian Economic Papers, 36 (68), 106-113.

Oosterbeek, H. (1997). Returns from Computer-use: A simple test on the Productivity interpretation, Economics Letters, 55, 273-277.

Pierce, B. (1999). Compensation Inequality, BLS Working Paper No. 323, Bureau of Labor Statistics, U.S. Department of Labor, Washington.

Wagner, G.G., R.V. Burkhauser, F. Behringer (1993). The English Language Public Use File of the German Socio-Economic Panel Study, The Journal of Human Resources, 28 (2), 429-433. 


\section{Appendix}

Table A1: Description and Descriptive Statistics of Variables Used in the Regression Models

\begin{tabular}{|c|c|c|c|}
\hline \multirow[t]{2}{*}{ Variable } & \multirow{2}{*}{$\begin{array}{l}\text { Description } \\
\text { Dependent variable }\end{array}$} & \multicolumn{2}{|c|}{ Mean (SD) } \\
\hline & & Men & Women \\
\hline $\operatorname{lnminc}$ & Log monthly compensation rate, Deutsche Mark & $8.43(0.38)$ & $8.14(0.36)$ \\
\hline & Socio-demographic variables & & \\
\hline Age & Age in years & 39.88 (10.74) & $36.04(11.12)$ \\
\hline Married & Marital status: $1=$ married couple, else $=0$ & 0.71 & 0.45 \\
\hline Region0 & $\begin{array}{l}\text { Regional Dummy: } 1=\text { Berlin, else }=0 \\
\text { Reference category }\end{array}$ & 0.03 & 0.05 \\
\hline Region1 & Regional Dummy: $1=$ Schleswig-Holstein, else $=0$ & 0.04 & 0.03 \\
\hline Region2 & Regional Dummy: 1=Hamburg, else $=0$ & 0.02 & 0.02 \\
\hline Region3 & Regional Dummy: $1=$ Lower Saxony, else $=0$ & 0.11 & 0.11 \\
\hline Region4 & Regional Dummy: $1=$ Bremen, else $=0$ & 0.01 & 0.01 \\
\hline Region5 & Regional Dummy: $1=$ North Rhine-Westphalia, else $=0$ & 0.28 & 0.28 \\
\hline Region6 & Regional Dummy: $1=$ Hesse, else $=0$ & 0.09 & 0.08 \\
\hline Region7 & Regional Dummy: $1=$ Rhineland-Palatinate/Saarland, else $=0$ & 0.08 & 0.08 \\
\hline Region8 & Regional Dummy: 1=Baden-Württemberg, else = 0 & 0.16 & 0.16 \\
\hline Region9 & Regional Dummy: 1=Bavaria, else $=0$ & 0.18 & 0.19 \\
\hline & Education and work experience & & \\
\hline Edu & Length of education in years & $11.62(2.27)$ & $11.35(2.02)$ \\
\hline Senior & Work experience at the same employer in years (seniority) & $12.24(10.07)$ & $8.57(7.77)$ \\
\hline Expfull & Previous work experience as full-time employee in years & $18.50(11.49)$ & $12.66(9.61)$ \\
\hline Exppart & Previous work experience as part-time employee in years & $0.26(1.33)$ & $1.39(3.43)$ \\
\hline & Job characteristics & & \\
\hline Hours & Actual working hours & $43.01(6.20)$ & $40.90(4.03)$ \\
\hline Public & Work in the public sector: $1=y e s$, else $=0$ & 0.17 & 0.31 \\
\hline Change & Change of job: $1=y e s$, else $=0$ & 0.11 & 0.15 \\
\hline Job0 & $\begin{array}{l}\text { No training necessary for the job: } 1=y e s \text {, else }=0 \text {; } \\
\text { Reference category }\end{array}$ & 0.02 & 0.04 \\
\hline Job1 & Briefing or courses necessary for the job: $1=y e s$, else $=0$ & 0.27 & 0.29 \\
\hline Job2 & Vocational training necessary for the job: $1=y e s$, else $=0$ & 0.57 & 0.62 \\
\hline Job3 & College/University necessary for the job: $1=y e s$, else $=0$ & 0.13 & 0.05 \\
\hline Jobcat0 & Job category: $1=$ Manufacturing, else $=0 ;$ Reference category & 0.50 & 0.14 \\
\hline Jobcat1 & Job category: $1=$ Science, else $=0$ & 0.19 & 0.18 \\
\hline Jobcat2 & Job category: $1=$ Management, else $=0$ & 0.04 & 0.02 \\
\hline Jobcat3 & Job category: $1=$ Office/Administration, else $=0$ & 0.16 & 0.46 \\
\hline Jobcat4 & Job category: $1=$ Commerce, else $=0$ & 0.05 & 0.10 \\
\hline Jobcat5 & Job category: $1=$ Services, else $=0$ & 0.04 & 0.08 \\
\hline Jobcat6 & Job category: $1=$ Plants/Animals, else $=0$ & 0.01 & 0.01 \\
\hline Bluecol & Blue collar worker $=1$, else $=0$ & 0.49 & 0.20 \\
\hline Bluecol0 & Blue collar worker: $1=$ unskilled, else $=0 ;$ Reference category & 0.01 & 0.03 \\
\hline Bluecol1 & Blue collar worker: $1=$ skilled, else $=0$ & 0.13 & 0.11 \\
\hline Bluecol2 & Blue collar worker: $1=$ semiskilled, else $=0$ & 0.28 & 0.05 \\
\hline Bluecol3 & Blue collar worker: $1=$ foreman, else $=0$ & 0.05 & 0.01 \\
\hline Bluecol4 & Blue collar worker: $1=$ master, else=0 & 0.02 & 0.00 \\
\hline Whiteco0 & White collar worker: $1=$ foreman, else $=0$; Reference category & 0.03 & 0.00 \\
\hline
\end{tabular}




\begin{tabular}{|c|c|c|c|}
\hline Whiteco1 & White collar worker: $1=$ without vocational training, else $=0$ & 0.02 & 0.10 \\
\hline Whiteco2 & White collar worker: $1=$ with vocational training, else $=0$ & 0.11 & 0.26 \\
\hline Whiteco3 & White collar worker: $1=$ qualified occupation, else $=0$ & 0.20 & 0.37 \\
\hline Whiteco4 & White collar worker: $1=$ highly qualified occupation, else $=0$ & 0.14 & 0.07 \\
\hline \multirow[t]{2}{*}{ Whiteco5 } & White collar worker: $1=$ executive function, else $=0$ & 0.01 & 0.01 \\
\hline & Industry (Reference category: all other branches) & & \\
\hline Branch1 & Branch: 1=Energy/Water, else $=0$ & 0.03 & 0.01 \\
\hline Branch2 & Branch: $1=$ Chemicals, else $=0$ & 0.06 & 0.04 \\
\hline Branch3 & Branch: $1=$ Plastics, else $=0$ & 0.01 & 0.01 \\
\hline Branch4 & Branch: $1=$ Stone, else $=0$ & 0.01 & 0.01 \\
\hline Branch5 & Branch: $1=$ Metal, else $=0$ & 0.10 & 0.05 \\
\hline Branch6 & Branch: $1=$ Wood, else $=0$ & 0.04 & 0.02 \\
\hline Branch7 & Branch: $1=$ Textiles, else $=0$ & 0.01 & 0.04 \\
\hline Branch8 & Branch: $1=$ Food, else $=0$ & 0.03 & 0.02 \\
\hline Branch9 & Branch: $1=$ Construction, else $=0$ & 0.11 & 0.02 \\
\hline Branch 10 & Branch: $1=$ Wholesale/Retail, else $=0$ & 0.08 & 0.14 \\
\hline Branch11 & Branch: $1=$ Transport, else $=0$ & 0.05 & 0.02 \\
\hline Branch12 & Branch: $1=$ Banking $/$ Insurance, else $=0$ & 0.05 & 0.09 \\
\hline Branch13 & Branch: $1=$ Other services, else $=0$ & 0.08 & 0.25 \\
\hline \multirow[t]{2}{*}{ Branch14 } & Branch: 1=Non-Profit, else $=0$ & 0.02 & 0.05 \\
\hline & Firm size & & \\
\hline Size1 & Firm size $<5$ employees & 0.08 & 0.10 \\
\hline Size2 & Firm size $>5$ and $<20$ employees & 0.08 & 0.09 \\
\hline Size3 & Firm size $>20$ and $<200$ employees & 0.26 & 0.28 \\
\hline Size4 & Firm size $>200$ and $<2000$ employees & 0.27 & 0.28 \\
\hline \multirow[t]{2}{*}{ Size0 } & Firm size > 2000 employees; Reference category & 0.31 & 0.25 \\
\hline & $\mathrm{PC}$ variables & & \\
\hline NoPC & $\begin{array}{l}\text { Did not use a computer at all: } 1=y e s, \text { else }=0 \text {; } \\
\text { Reference category }\end{array}$ & 0.60 & 0.57 \\
\hline PChome & Used a computer at home only: $1=y e s$, else $=0$ & 0.06 & 0.02 \\
\hline PCwork & Used a computer at work only: $1=y e s$, else $=0$ & 0.17 & 0.30 \\
\hline \multirow[t]{2}{*}{ PCboth } & Used a computer at home and at work: $1=y e s$, else $=0$ & 0.17 & 0.11 \\
\hline & Future PC variables & & \\
\hline $\mathrm{PC} 00$ & $\begin{array}{l}\text { Did not use a computer at work neither today nor in the } \\
\text { future; Reference category }\end{array}$ & 0.68 & 0.63 \\
\hline $\mathrm{PC} 01$ & $\begin{array}{l}\text { Did not use a computer today (1985-1987), but in the future } \\
\text { (after 1987) }\end{array}$ & 0.30 & 0.35 \\
\hline PC11 & Used a computer today and in future & 0.02 & 0.02 \\
\hline $\mathrm{PC} 0$ & $\begin{array}{l}\text { Did not use a computer today, but in the immediate future } \\
\text { (before 1987) }\end{array}$ & 0.01 & 0.01 \\
\hline $\mathrm{PC} 1$ & $\begin{array}{l}\text { Did not use a computer today, but in the near future (between } \\
1988 \text { and 1990) }\end{array}$ & 0.10 & 0.14 \\
\hline PC2 & $\begin{array}{l}\text { Did not use a computer today, but in the medium future } \\
\text { (between } 1991 \text { and 1994) }\end{array}$ & 0.11 & 0.13 \\
\hline PC3 & $\begin{array}{l}\text { Did not use a computer today, but in the distant future (after } \\
\text { 1994) }\end{array}$ & 0.08 & 0.07 \\
\hline
\end{tabular}

Source: GSOEP, 1985-1999. 
Table A2: Model (II): Longitudinal Regressions With PCwork for men

\begin{tabular}{|c|c|c|c|c|c|c|}
\hline \multirow{3}{*}{$\begin{array}{l}\text { Variable } \\
\text { Intercept }\end{array}$} & \multirow{2}{*}{\multicolumn{2}{|c|}{$\begin{array}{c}\text { Pooled OLS } \\
\text { Parameter }\end{array}$}} & \multirow{2}{*}{\multicolumn{2}{|c|}{$\frac{\text { Random Effects }}{\text { Parameter }}$}} & \multirow{2}{*}{\multicolumn{2}{|c|}{ Fixed Effects }} \\
\hline & & & & & & \\
\hline & $7.3160^{* *}$ & $(0.0303)$ & $7.1026^{* *}$ & $(0.9507)$ & $6.6204^{* *}$ & $(0.0914)$ \\
\hline Year86 & $0.0378^{* *}$ & (0.0104) & $0.0342^{* *}$ & (0.0067) & -0.0000 & $(0.0064)$ \\
\hline Year87 & $0.0756^{* *}$ & (0.0102) & $0.0724^{* *}$ & (0.0066) & 0.0075 & $(0.0061)$ \\
\hline Year88 & $0.1170^{* *}$ & $(0.0102)$ & $0.1059^{* *}$ & $(0.0067)$ & 0.0069 & (0.0059) \\
\hline Year89 & $0.1566^{* *}$ & $(0.0010)$ & $0.1466^{* *}$ & $(0.0066)$ & $0.0160^{* *}$ & (0.0057) \\
\hline Year90 & $0.2047^{* * *}$ & $(0.0101)$ & $0.1960^{* *}$ & $(0.0067)$ & $0.0354^{* *}$ & (0.0057) \\
\hline Year91 & $0.1868^{* *}$ & $(0.0102)$ & $0.2059^{* *}$ & $(0.0070)$ & $0.0217^{* * *}$ & (0.0057) \\
\hline Year92 & $0.2467^{* *}$ & $(0.0102)$ & $0.2653^{* *}$ & $(0.0071)$ & $0.0507^{* *}$ & (0.0057) \\
\hline Year93 & $0.2843^{* *}$ & $(0.0101)$ & $0.3049^{* *}$ & $(0.0072)$ & $0.0586^{* *}$ & $(0.0056)$ \\
\hline Year94 & $0.3054^{* *}$ & $(0.0102)$ & $0.3285^{* *}$ & $(0.0073)$ & $0.0526^{* *}$ & $(0.0057)$ \\
\hline Year95 & $0.3281^{* *}$ & $(0.0101)$ & $0.3489^{* *}$ & $(0.0075)$ & $0.0410^{* *}$ & (0.0058) \\
\hline Year96 & $0.3635^{* *}$ & $(0.0102)$ & $0.3941^{* *}$ & $(0.0077)$ & $0.0573^{* *}$ & $(0.0060)$ \\
\hline Year97 & $0.3727^{* *}$ & $(0.0102)$ & $0.3978^{* *}$ & $(0.0078)$ & $0.0285^{* *}$ & (0.0061) \\
\hline Year98 & $0.3692^{* *}$ & $(0.0104)$ & $0.4034^{* *}$ & $(0.0081)$ & 0.0068 & (0.0064) \\
\hline Year99 & $0.3782^{* *}$ & $(0.0105)$ & $0.4161^{* *}$ & $(0.0084)$ & - & - \\
\hline Age & $0.0054^{* *}$ & $(0.0006)$ & $0.0075^{* *}$ & $(0.0012)$ & $0.0291^{* *}$ & $(0.0032)$ \\
\hline Married & $0.0530^{* *}$ & $(0.0045)$ & $0.0514^{* *}$ & $(0.0048)$ & $0.0474^{* *}$ & $(0.0051)$ \\
\hline Region1 & $-0.0325^{*}$ & $(0.0136)$ & -0.0349 & $(0.0278)$ & -0.0863 & (0.0495) \\
\hline Region2 & 0.0139 & $(0.0166)$ & 0.0056 & (0.0309) & -0.0853 & (0.0501) \\
\hline Region3 & $-0.0340^{* *}$ & $(0.0113)$ & $-0.0622^{* *}$ & $(0.0240)$ & $-0.1590^{* *}$ & (0.0443) \\
\hline Region4 & $-0.0486^{*}$ & $(0.0192)$ & -0.0618 & $(0.0358)$ & $-0.1135^{*}$ & $(0.0576)$ \\
\hline Region5 & -0.0083 & (0.0106) & -0.0355 & $(0.0227)$ & $-0.1563^{* *}$ & (0.0430) \\
\hline Region6 & -0.0027 & $(0.0116)$ & -0.0103 & $(0.0249)$ & $-0.0981^{*}$ & $(0.0486)$ \\
\hline Region7 & $-0.0291^{*}$ & $(0.0118)$ & $-0.0735^{* *}$ & $(0.0255)$ & $-0.2042^{* *}$ & $(0.0510)$ \\
\hline Region8 & 0.0144 & $(0.0110)$ & 0.0197 & $(0.0237)$ & 0.0370 & $(0.0476)$ \\
\hline Region9 & -0.0121 & (0.0109) & -0.0082 & $(0.0231)$ & -0.0505 & $(0.0427)$ \\
\hline Edu & $0.0219^{* *}$ & (0.0013) & $0.0366^{* *}$ & $(0.0022)$ & $0.0144^{* *}$ & $(0.0045)$ \\
\hline Senior & $0.0035^{* *}$ & $(0.0007)$ & $0.0023^{* *}$ & $(0.0006)$ & $0.0014^{*}$ & (0.0007) \\
\hline Senior $^{2}$ & -0.0000 & $(0.0000)$ & 0.0000 & $(0.0000)$ & 0.0000 & (0.0000) \\
\hline Expfull & $0.0149^{* *}$ & $(0.0009)$ & $0.0165^{* *}$ & $(0.0014)$ & $0.0281^{* *}$ & $(0.0036)$ \\
\hline Expfull $^{2}$ & $-0.0004^{* *}$ & $(0.0000)$ & $-0.0004^{* *}$ & $(0.0000)$ & $-0.0004^{* *}$ & $(0.0000)$ \\
\hline Exppart & $-0.0256^{* * *}$ & $(0.0026)$ & $-0.0295^{* *}$ & $(0.0050)$ & -0.0099 & (0.0104) \\
\hline Exppart $^{2}$ & $0.0009^{* * *}$ & $(0.0001)$ & $0.0010^{* *}$ & $(0.0003)$ & 0.0000 & (0.0018) \\
\hline Hours & $0.0098^{* *}$ & $(0.0003)$ & $0.0066^{* *}$ & $(0.0003)$ & $0.0062^{* *}$ & $(0.0003)$ \\
\hline Public & $-0.0560^{* *}$ & $(0.0055)$ & $-0.0401^{* *}$ & $(0.0066)$ & $-0.0317^{* * *}$ & (0.0073) \\
\hline Change & $-0.0565^{* *}$ & $(0.0062)$ & $-0.0494^{* *}$ & $(0.0043)$ & $-0.0456^{* *}$ & (0.0043) \\
\hline Job1 & 0.0119 & $(0.0119)$ & 0.0017 & $(0.0089)$ & -0.0033 & (0.0089) \\
\hline Job2 & $0.0332^{* *}$ & $(0.0122)$ & 0.0078 & $(0.0094)$ & -0.0067 & (0.0095) \\
\hline Job3 & $0.1695^{* *}$ & $(0.0143)$ & $0.0821^{* *}$ & $(0.0120)$ & $0.0406^{* *}$ & $(0.0124)$ \\
\hline Jobcat1 & -0.0086 & $(0.0077)$ & 0.0141 & $(0.0078)$ & -0.0065 & $(0.0084)$ \\
\hline Jobcat2 & $0.1195^{* * *}$ & (0.0108) & $0.0610^{* *}$ & $(0.0097)$ & $0.0267^{* * *}$ & (0.0100) \\
\hline
\end{tabular}




\begin{tabular}{|c|c|c|c|c|c|c|}
\hline Jobcat3 & $-0.0253^{* * *}$ & $(0.0073)$ & 0.0024 & $(0.0075)$ & -0.0080 & $(0.0081)$ \\
\hline Jobcat4 & -0.0189 & $(0.0102)$ & 0.0133 & $(0.0102)$ & 0.0078 & $(0.0109)$ \\
\hline Jobcat5 & $-0.1133^{* *}$ & $(0.0103)$ & $-0.0828^{* *}$ & (0.0126) & $-0.0496^{* *}$ & $(0.0143)$ \\
\hline Jobcat6 & $-0.0610^{* *}$ & (0.0189) & -0.0301 & (0.0274) & 0.0020 & $(0.0333)$ \\
\hline Bluecol & $-0.3019^{* *}$ & $(0.0206)$ & $-0.1660^{* *}$ & (0.0169) & $-0.1073^{* *}$ & $(0.0173)$ \\
\hline Bluecol1 & $0.0457^{*}$ & $(0.0180)$ & $0.0345^{* *}$ & (0.0133) & 0.0234 & $(0.0134)$ \\
\hline Bluecol2 & $0.0904^{* *}$ & $(0.0180)$ & $0.0570^{* *}$ & (0.0140) & $0.0346^{*}$ & $(0.0142)$ \\
\hline Bluecol3 & $0.1567^{* *}$ & (0.0193) & $0.1021^{* *}$ & (0.0153) & $0.0746^{* *}$ & $(0.0155)$ \\
\hline Bluecol4 & $0.2719^{* *}$ & $(0.0215)$ & $0.1292^{* *}$ & (0.0174) & $0.0812^{* *}$ & $(0.0177)$ \\
\hline Whiteco1 & $-0.2233^{* *}$ & $(0.0163)$ & $-0.1019^{* *}$ & (0.0134) & $-0.0742^{* *}$ & $(0.0135)$ \\
\hline Whiteco2 & $-0.1196^{* *}$ & $(0.0122)$ & $-0.0629^{* *}$ & (0.0103) & $-0.0560^{* *}$ & $(0.0104)$ \\
\hline Whiteco3 & -0.0191 & $(0.0117)$ & -0.0115 & $(0.0100)$ & -0.0144 & $(0.0101)$ \\
\hline Whiteco4 & $0.0743^{* *}$ & $(0.0127)$ & $0.0443^{* *}$ & (0.0108) & $0.0313^{* *}$ & $(0.0109)$ \\
\hline Whiteco5 & $0.1768^{* *}$ & $(0.0198)$ & $0.0848^{* *}$ & $(0.0159)$ & $0.0540^{* *}$ & $(0.0159)$ \\
\hline Branch1 & $0.0344^{* *}$ & $(0.0112)$ & 0.0220 & (0.0133) & 0.0135 & $(0.0142)$ \\
\hline Branch2 & $0.0502^{* *}$ & $(0.0079)$ & $0.0257^{* *}$ & (0.0099) & 0.0069 & $(0.0109)$ \\
\hline Branch3 & -0.0192 & $(0.0152)$ & 0.0053 & $(0.0149)$ & -0.0013 & $(0.0155)$ \\
\hline Branch4 & $-0.0423^{* *}$ & $(0.0149)$ & $-0.0511^{* *}$ & (0.0158) & $-0.0616^{* *}$ & $(0.0165)$ \\
\hline Branch5 & $-0.0199^{* *}$ & $(0.0065)$ & 0.0037 & $(0.0061)$ & 0.0099 & $(0.0063)$ \\
\hline Branch6 & 0.0157 & (0.0097) & 0.0008 & (0.0119) & -0.0033 & $(0.0130)$ \\
\hline Branch7 & $-0.1673^{* *}$ & $(0.0159)$ & -0.0132 & (0.0178) & 0.0279 & $(0.0187)$ \\
\hline Branch8 & $-0.0638^{* *}$ & (0.0106) & -0.0121 & (0.0123) & 0.0136 & $(0.0132)$ \\
\hline Branch9 & 0.0114 & (0.0066) & 0.0125 & (0.0073) & $0.0172^{*}$ & $(0.0078)$ \\
\hline Branch10 & $-0.1316^{* *}$ & (0.0079) & $-0.0493^{* *}$ & (0.0074) & $-0.0284^{* *}$ & $(0.0077)$ \\
\hline Branch11 & $-0.0264^{* *}$ & $(0.0085)$ & -0.0064 & $(0.0100)$ & 0.0047 & $(0.0109)$ \\
\hline Branch12 & $0.0221^{*}$ & (0.0093) & 0.0196 & (0.0137) & -0.0066 & $(0.0162)$ \\
\hline Branch13 & $-0.0480^{* *}$ & (0.0076) & $-0.0302^{* *}$ & (0.0082) & $-0.0209^{*}$ & $(0.0088)$ \\
\hline Branch14 & $-0.0768^{* *}$ & $(0.0145)$ & $-0.0409^{* *}$ & $(0.0151)$ & $-0.0457^{* *}$ & $(0.0159)$ \\
\hline Size1 & $-0.2174^{* *}$ & $(0.0075)$ & $-0.1212^{* * *}$ & $(0.0075)$ & $-0.0788^{* *}$ & $(0.0081)$ \\
\hline Size2 & $-0.1682^{* *}$ & $(0.0075)$ & $-0.0995^{* *}$ & (0.0074) & $-0.0689^{* *}$ & $(0.0078)$ \\
\hline Size3 & $-0.1086^{* *}$ & (0.0049) & $-0.0517^{* *}$ & (0.0053) & $-0.0283^{* *}$ & $(0.0057)$ \\
\hline Size4 & $-0.0558^{* *}$ & $(0.0047)$ & $-0.0240^{* *}$ & (0.0047) & $-0.0122^{*}$ & $(0.0048)$ \\
\hline PCwork & $0.0253^{* *}$ & $(0.0048)$ & $0.0118^{*}$ & (0.0048) & -0.0008 & $(0.0050)$ \\
\hline Observations & \multicolumn{2}{|c|}{15,536} & \multicolumn{2}{|c|}{15,536} & \multicolumn{2}{|c|}{15,536} \\
\hline $\mathrm{R}^{2}$ & \multicolumn{2}{|c|}{0.6814} & \multicolumn{2}{|c|}{0.6524} & \multicolumn{2}{|c|}{0.1524} \\
\hline
\end{tabular}

Source: GSOEP, 1985-1999.

Notes: ${ }^{*}$ Statistically significant at the $5 \%$ level, ${ }^{* *}$ at the $1 \%$ level. Standard errors in parentheses. 


\section{IZA Discussion Papers}

\begin{tabular}{|c|c|c|c|c|}
\hline No. & Author(s) & Title & Area & Date \\
\hline 414 & $\begin{array}{l}\text { A. Frederiksen } \\
\text { N. Westergaard- } \\
\text { Nielsen }\end{array}$ & Where Did They Go? & 1 & $01 / 02$ \\
\hline 415 & $\begin{array}{l}\text { M. Bertrand } \\
\text { F. Kramarz }\end{array}$ & $\begin{array}{l}\text { Does Entry Regulation Hinder Job Creation? } \\
\text { Evidence from the French Retail Industry }\end{array}$ & 6 & $01 / 02$ \\
\hline 416 & $\begin{array}{l}\text { B. Crépon } \\
\text { F. Kramarz }\end{array}$ & $\begin{array}{l}\text { Employed } 40 \text { Hours or Not-Employed 39: } \\
\text { Lessons from the } 1982 \text { Mandatory Reduction of } \\
\text { the Workweek }\end{array}$ & 6 & $01 / 02$ \\
\hline 417 & J. Wagner & $\begin{array}{l}\text { Taking a Second Chance: } \\
\text { Entrepreneurial Restarters in Germany }\end{array}$ & 1 & $01 / 02$ \\
\hline 418 & $\begin{array}{l}\text { M. Frölich } \\
\text { P. A. Puhani }\end{array}$ & $\begin{array}{l}\text { Immigration and Heterogeneous Labor in } \\
\text { Western Germany: A Labor Market } \\
\text { Classification Based on Nonparametric } \\
\text { Estimation }\end{array}$ & 2 & $01 / 02$ \\
\hline 419 & $\begin{array}{l}\text { P. Frijters } \\
\text { J. P. Haisken-DeNew } \\
\text { M. A. Shields }\end{array}$ & $\begin{array}{l}\text { The Value of Reunification in Germany: } \\
\text { An Analysis of Changes in Life Satisfaction }\end{array}$ & 6 & $01 / 02$ \\
\hline 420 & $\begin{array}{l}\text { Å. Rosén } \\
\text { E. Wasmer }\end{array}$ & $\begin{array}{l}\text { Higher Education Levels, Firms' Outside Options } \\
\text { and the Wage Structure }\end{array}$ & 1 & $01 / 02$ \\
\hline 421 & P. Manzini & Divide et Impera: Negotiating with a Stakeholder & 6 & $02 / 02$ \\
\hline 422 & $\begin{array}{l}\text { J. T. Addison } \\
\text { L. Bellmann } \\
\text { C. Schnabel } \\
\text { J. Wagner }\end{array}$ & $\begin{array}{l}\text { The Long Awaited Reform of the German Works } \\
\text { Constitution Act }\end{array}$ & 6 & $02 / 02$ \\
\hline 423 & $\begin{array}{l}\text { E. Feess } \\
\text { G. Muehlheusser }\end{array}$ & Transfer Fee Regulations in European Football & 1 & $02 / 02$ \\
\hline 424 & $\begin{array}{l}\text { F. Büchel } \\
\text { M. van Ham }\end{array}$ & $\begin{array}{l}\text { Overeducation, Regional Labour Markets and } \\
\text { Spatial Flexibility }\end{array}$ & 3 & $02 / 02$ \\
\hline 425 & F. Büchel & $\begin{array}{l}\text { Successful Apprenticeship-to-Work Transitions: } \\
\text { On the Long-Term Change in Significance of the } \\
\text { German School-Leaving Certificate }\end{array}$ & 3 & $02 / 02$ \\
\hline 426 & $\begin{array}{l}\text { J. Hartog } \\
\text { W. P. M. Vijverberg }\end{array}$ & $\begin{array}{l}\text { Do Wages Really Compensate for Risk Aversion } \\
\text { and Skewness Affection? }\end{array}$ & 5 & $02 / 02$ \\
\hline 427 & D. Del Boca & $\begin{array}{l}\text { The Effect of Child Care and Part Time } \\
\text { Opportunities on Participation and Fertility } \\
\text { Decisions in Italy }\end{array}$ & 6 & $02 / 02$ \\
\hline 428 & D. Del Boca & $\begin{array}{l}\text { Mothers, Fathers and Children after Divorce: } \\
\text { The Role of Institutions }\end{array}$ & 6 & $02 / 02$ \\
\hline 429 & $\begin{array}{l}\text { S. Anger } \\
\text { J. Schwarze }\end{array}$ & $\begin{array}{l}\text { Does Future PC Use Determine Our Wages } \\
\text { Today? Evidence from German Panel Data }\end{array}$ & 5 & $02 / 02$ \\
\hline
\end{tabular}

